\title{
VISUALISATIONS OF THE HUMAN IMPACTS ON THE EARTH'S SURFACE
}

\author{
VIZUALIZACIJA KOT VPLIV ČLOVEKA NA ZEMELJSKO POVRŠJE
}

\author{
Tomaž PODOBNIKAR ${ }^{1,2}$
}

\begin{abstract}
UDC 911.2:551.4

Tomaž Podobnikar: Visualisations of the Human Impacts on the Earth's Surface

The objective is to discuss the human impacts to the changing of the landscape surface. The study surface is mainly karstic part of Slovenia. The primary data sources are digital elevation models (DEMs) as continuous surface data, supported with aerial photographs, satellite images and older topographic maps. This study is supplemented with textual information about of historical surfaces. Geomorphologically high quality DEM of Slovenia with $12.5 \mathrm{~m}$ resolution uncovered many human impacts to the terrain surface, which could not be perceived before using any classical surveying techniques. Particularly on the karstic areas, changes of the surface as a consequence of highway constructions and developing of the stone quarries are well seen. Additionally is involved a database of natural (ridges, valleys, peaks, sinkholes) and antropogenic features (stone and gravel quarries, standing waters, different types of roads and railways) on the current terrain surface. Even more surface changes were found on the LIDAR-based DEM of $1 \mathrm{~m}$ resolution. Some human impacts to the surface changes from prehistory until today were analysed with many visual techniques and confirmed with objective numerical methods. The results show that is the human impact on the Earth's surface important factor that grows exponentially with time.
\end{abstract}

Key words: digital elevation model, GIS analysis, surface changes, visualisation.

\section{Izvleček}

UDK 911.2:551.4

Tomaž Podobnikar: Vizualizacija kot vpliv človeka na zemeljsko površje

Namen prispevka je pretresti vplive človeka na spreminjanje značilnosti površja pokrajine. Za študijsko območje je bil izbran pretežno kraški del Slovenije. Podatki za analize so bili digitalni modeli reliefa (DMR), podprti $\mathrm{z}$ aero in satelitskimi posnetki ter s starejšimi topografskimi kartami. $\mathrm{V}$ pomoč so bili opisi zgodovinskih pokrajin. Na geomorfološko visokokakovostnem DMR Slovenije ločljivosti $12,5 \mathrm{~m}$ je bilo zaznati veliko človekovih vplivov na površje, kakršnih do sedaj s klasično zemljemersko tehniko nismo mogli določiti. Posebno na kraških območjih so opazni poteki avtocest in območja kamnolomov kot posledice spreminjanja površja. Izdelali smo zbirko podatkov naravnih (grebeni, doline, vrhovi, vrtače) in umetnih (kamnolomi, peskokopi, stoječe vode, različne kategorije cest in železnic) značilnosti površja. Še več sprememb površja smo našli na lidarskem DMR-ju ločljivosti $1 \mathrm{~m}$. Analizirali smo izbrane človekove vplive na spremembe površja in pri tem uporabili več vizualnih tehnik, ki smo jih podprli z objektivnimi numeričnimi metodami. Rezultati analiz kažejo, da je vliv človeka na zemeljsko površje vedno večji ter in upoštevanja vreden.

Ključne besede: digitalni model reliefa, analize v GIS, sprememba površja, vizualizacija.

\section{INTRODUCTION}

The surface of the Earth is a dynamic formation. It is non-stop and step by step temporally changing in natural or anthropogenic way. Continental lithosphere plates are relatively slowly sliding beside each other, drifting apart or colliding. Earthquakes or volcano eruptions and additional phenomena like landslides or rockfalls acceler-

\footnotetext{
${ }^{1}$ Scientific Research Centre of Slovenian Academy for Sciences and Arts, Novi trg 2, SI-1000 Ljubljana, Slovenia

${ }^{2}$ Institute of Photogrammetry and Remote Sensing, Vienna University of Technology, Gußhausstr. 27-29, A-1040 Vienna, Austria

Received/Prejeto: 18.09.2006
} 
ate the processes of landscape changes. Other, slower processes, like mechanical or chemical erosion, deposition, also influences to the surface shape. Soil and vegetation cover slow-down the surface change processes. During the last few decades, especially many human activities cause dramatic Earth's surface changes. Many of them are just different buildings - houses or bridges that are objects on the terrain and therefore more influence to the landscape changes than to the surface. More dramatic changes are highway constructions, stone sand and gravel quarries and clay pits, or rubbish dumps. The geomorphology or terrain surface has been therefore incorrigibly changed.

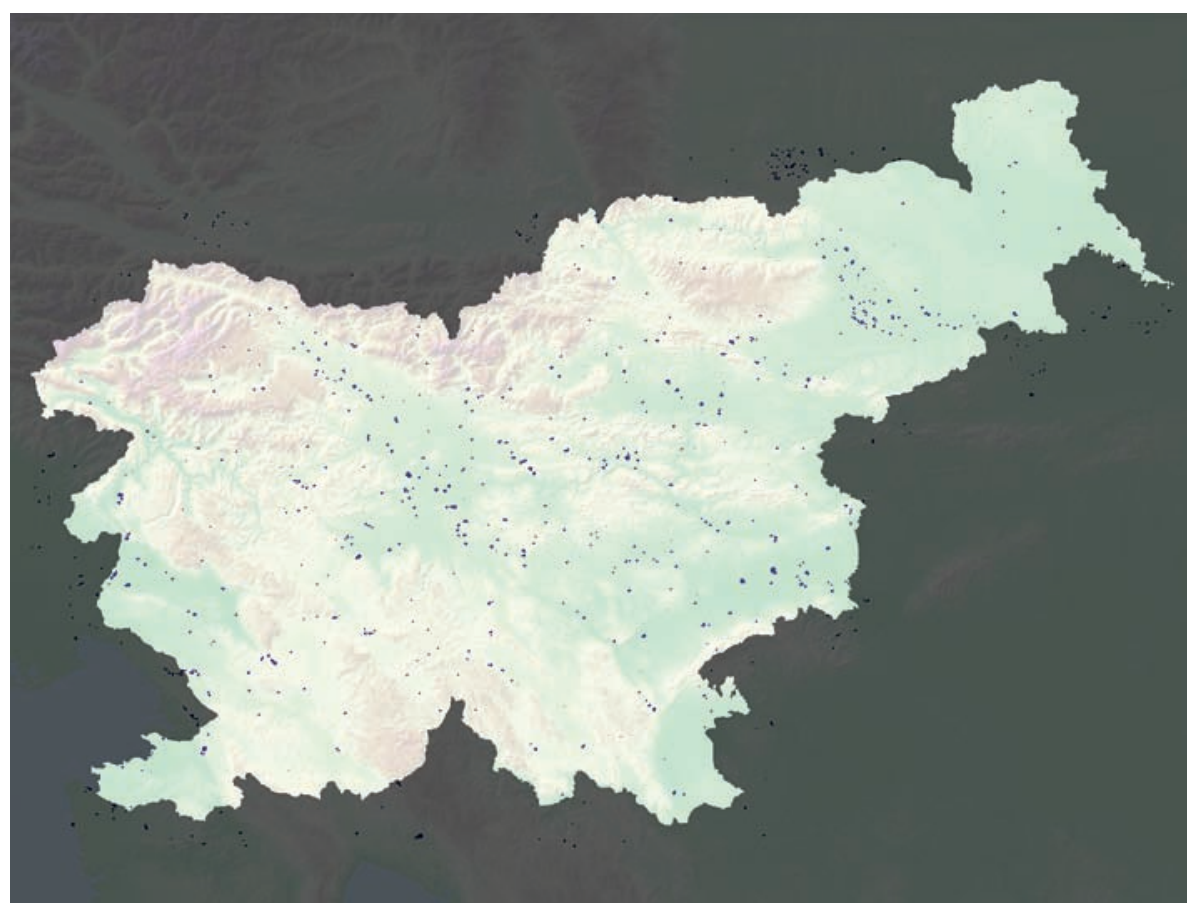

Fig. 1: Database of stone quarries in Slovenia, produced for DEM 12.5 modelling.

Human influences on the Earth's surface changes are remarkable for the more of last centuries. We can observe their activities since they have higher impact to the environmental and landscape changes than any other impacts like those from the animals. Anyway, coral polyps are slowly building coral reefs with their skeleton for millenniums; beavers have been constructing dams to regulate level of the water, etc. The early consequences of landscape changes due to human needs like levelling the fields, building terraces, constructing the walls, etc. are easily perceivable. We can still easily find walls of the prehistoric hillforts (cf. during the Bronze Age, Fig. 6). On the surface is also perceivable the old pre Roman course of river Ljubljanica (cf. Fig. 8a). Romans shifted the river stream to establish a stone quarry in Podpeč for build- ing up and supporting their city Emona. For the most of surface changes done until the 20 century we can consider that people did them with high respecting of the environment. In fact they could not drastically change the Earth's surface because the work was manual or using low power machines. But nevertheless the effect of their changes of the landscape has been naturally or on the other way blurred since that time by so called renaturalisation process.

Newer human's impacts to surface are more and more brutal. Landscape is wounded with newer and bigger structures and other irreversible interventions to the surface. On Slovenian landscape is the most remarkable highways construction. That network will be build up in few years in a total length of $518 \mathrm{~km}$ (DARS, 2006). This will change at least $25 \mathrm{~km} 2$ of surface. That means converted to square shape around 5 x $5 \mathrm{~km}$, what is comparable with the area of town Ljubljana. For $1 \mathrm{~km}$ of highway around $18,000 \mathrm{~m}^{3}$ of material is needed acquired on the area of highways and form stone quarries (DARS, 2006), with a total amount of around $0.01 \mathrm{~km}^{3}$ (or more than 200 x $200 \times 200 \mathrm{~m}$ ). During the modelling of digital elevation model (DEM) of Slovenia we registered 713 stone quarries to our database (included 295 gravel quarries and 127 abandoned ones) that cover at least $15 \mathrm{~km}^{2}$ of Slovenia (Fig. 1). If we consider almost 1.4 million of buildings that exist in Slovenia, with approximate changed surface of $200 \mathrm{~m}^{2}$, it sums up to $280 \mathrm{~km}^{2}$. We should add other roads, rubbish dumps and tailings or other material deposits, too. Applying very rough estimation, currently at least $2 \%$ of Slovenia's surface is much changed by humans (cf. Fig. 10), but the impact area is much larger (e.g. considering impact areas around buildings, ski resorts).

Many other projects that ineligibly change the surface - especially on the karst area are easily perceived building of large buildings, ski resources, industrial trade-zones, power plants, mining activities, etc. Some of such projects are described: The location of the European Karst Museum (EKM, 2006) is planned on naturally undamaged area, in our opinion, more acceptable locations 


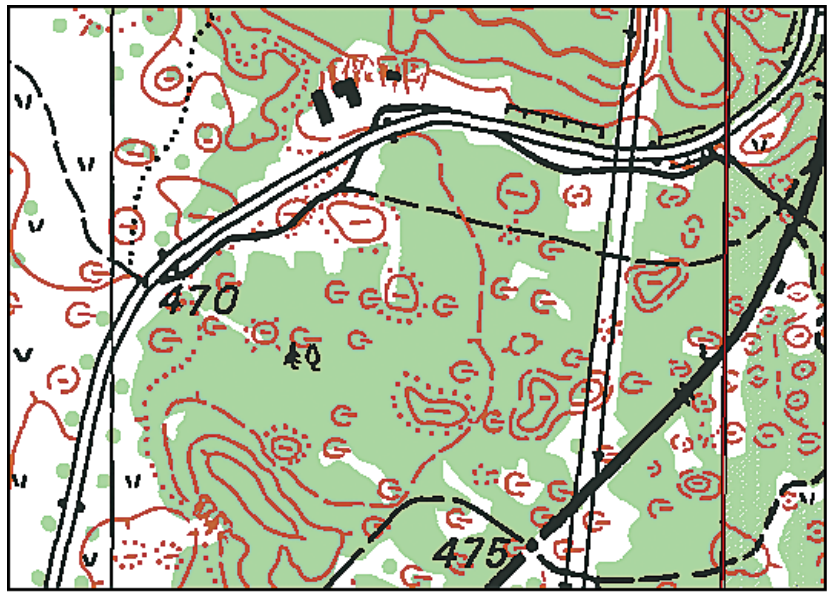

a

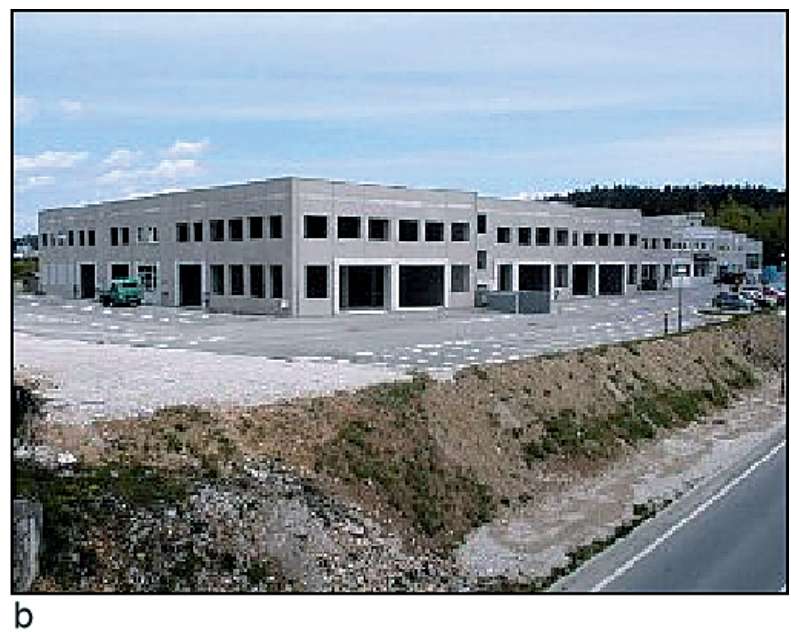

b

Fig. 2: a: Large area of primary rough natural karst surface (DTK25, (C) Surveying and Mapping Authority of RS) was b: completely flattened for industrial-trade zone Logatec.

should be considered such as degraded areas around - stone quarries or low quality urban areas. Most of ski resources are "improved" by flattening the ground and by building of the accommodation capacities (e.g. Kanin and Boevec). Planed buildings in industrial-trade zones like Sežana, Logatec or Cerknica-Podskrajnik changes larger areas completely (Fig. 2). The projects like wind power plants (i.e. Volovja reber) should be also planned with inclusion of more professional arguments than with political and capital power (Podobnikar and Zakšek, 2005) as at least many new roads should be built on vulnerable karst area. The other remarkable changes are depressions formed as consequences of mining - i.e. the lakes on the abandoned coal mine near Velenje are still increasing (Oštir, 2000; Komac, 2006). Morphological changes in this last case are conditionally acceptable for aesthetical and even ecological view, as they have nearly natural appearance comparing to other landscape patterns.

The changing of the Earth's surface and its visual impact is related with environmental aesthetics. It is temporally changes with newer reveals and even with the fashion. Aesthetics is the field of philosophy that studies the ways in which humans experience the world through their senses, or shortly, it means visual pleasing. Environmental aesthetics extends beyond the narrow confines of the art world to the aesthetic appreciation of humaninfluenced as well as natural environments (Carlson, 2002). Aesthetics is connected with scenic landscapes where most people reportedly enjoy most. A Visual Resource Management (VRM) is a system which involves inventorying scenic values and establishing management objectives (VRM, 2003). The values evaluate proposed activities and determine whether they conform to the management objectives. Beautification process of making aesthetical visual improvements is typical for urban areas but can be applied for the natural environment. Generally the environmental aesthetics is decreasing regarding mentioned criterion that is obvious applying visual analyses in this paper.

The motivation for this research was the inflation of anthropogenic changes that was considered during the DEM 12.5 of Slovenia production (Podobnikar, 2005b). For the integration of DEM from various data sources, special methods were developed for recent anthropogenic surface changes due to the problem that most of the human activities are not registered in 3D databases. With different approaches were integrated roads, highways, railways, buildings, stone quarries (surface mining), dams, and other changes, especially rubbish dumps. After those procedures the DEM didn't appear anymore geomorphologically natural. For the first time we could observe impacts of different kinds of the recent buildings, especially on the detailed map of Slovenia (Podobnikar, 2005a) and on the other developed visualisations of surface (Podobnikar, 2007). Such DEM can not be used for understanding geological details or natural forms of the Earth's surface. Additional motivations of this research were interesting topographic information from the older topographic maps that show environment with more natural surface characteristics than newer data sets. This data can be used also for understanding natural landscape and geological formations or for palaeo-DEM modelling (Podobnikar and Šinkovec, 2004). The DEMs and maps are important sources for monitoring the surface changes, but they are rather neglected in comparing with generally more attractive and mastered satellite images. 


\section{DATA SOURCES FOR VISUAL ANALYSIS}

Our study area was entire Slovenia with focus on the karst areas. The main data sources were DEMs. The other data sources that supported the study were topographic maps, especially historical maps, aerial photographs, and satellite images of different age. All of the data were digitised and georeferenced to the common coordinate reference of the Slovenian national cartographic system, bases on Gauss-Krüger coordinates. Overall high and known (evaluated) quality was the most important property for the data sources used in the study. Modelling the spatial data, analyses and visualisations were produced with tools based on geographical information systems (GIS).

Aerial photographs and satellite images are common and standard data sources for observation the changes of the Earth's surface. We have used some digital orthophotos from different periods from the Surveying and Mapping Authority of Republic Slovenia and high resolution satellite images available in Google Earth (Google, 2006).

The historical maps are the most important sources for the various spatial analyses of the historical landscapes, urban development, influences of the economy development, toponymes changes, land use, etc. (Podobnikar and Kokalj, 2007). Some information there is more implicitly noted, more difficult understandable and therefore less objective than from historical texts. Georeferencing of digitised versions of those maps is also not as trivial as for nowadays maps or satellite images, especially because of the unknown coordinate systems and unpredictable distortions due to simple techniques of measurements and sometimes mapping without any measurement. We used some older and new maps from Surveying and Mapping Authority of Republic Slovenia and historical maps that are up to 250 years old (the maps are listed below the figures).

With radar differential interferometry techniques (ESA, 2006; Oštir, 2000) we can track even small changes of the surface heights continuously and precisely over a particular area. A differential interferometry is useful for perception and measuring the changes of the surface consequences of earthquakes or some human's activities. With the radar interferometry can be produced numerically low to medium quality but geomorphically overall homogeneous DEM.

Using the aerial laser scanning equipment, a high quality LIDAR-DEM of $1 \mathrm{~m}$ resolution was produced for the area that transact Kras region in direction east-west, with dimensions of 2 by $20 \mathrm{~km}$. Primary usage of this data layer was vegetation density research for which the laser scanning methods are suitable and promising (Kobler, 2006).

DEMs are amongst the most applicable layers in GIS applications (Burrough and McDonnell, 1998). Because they are our main data source in this paper, we are going to describe it in higher detail. In general, DEM is considered as a "raster dataset" (grid). Each square cell of the grid contains the elevation value (height) for the centroid of the cell. The finite set of cell heights can be interpreted in two ways. With the first approach, each cell can represent a discrete area, hence the entire cell is assumed to be of the same value, and changes occur only at the border of the cells. With the second approach, the surface area between the cell centres is assumed to have some intermediate values. The second approach is closer to the DTM (digital terrain model) definition. DTM is considered a continuous, usually smoothed surface which includes, apart from the values of height (DEMs), other elements that describe the topographic surface, such as slope, aspect, curvature, gradient, skeleton (sinks /karst dolinas/, valleys /thalwegs/, saddles, ridges /crests/, and peaks), and others (Podobnikar, 2005b).

DEM is just a model of the Earth's surface. Its specification as a model includes: natural and artificial standing water surfaces, glacier surfaces, artificial terraces and dams, stone, sand and gravel quarries, surface mining processes, rubbish dumps and other deposits, mound and dikes or removal of earth for roads, railways, parking places, airports, levelling of original landscapes for easier moving or making fields, ameliorations of the river courses, and many other artificial changes of our surface (Podobnikar, 2005b). Buildings, for example houses or bridges are not considered to be part of DEM.

Historically, digital elevation models have been introduced in mid-fifties in the United States. The concepts of DEM production are connected with development of computer science, which enabled effective analytical data processing. In Slovenia the first researches for the DEM production started in the late sixties. In 1973 they started with production of DEM 100 for the whole of Slovenia. In 1975 DEM 500 for entire Slovenia had been produced (sources were topographical maps in scale 1:25,000, $1: 50,000$ and 1:100,000). The DEM 100 was finished in 1984 (sources were topographic maps in scale 1:5000 and $1: 25,000)$. In 2000 was produced InSAR DEM 25 that employed radar satellite images and some other data, and in 2001 a DEM 25 photogrammetrically from aerial photographs (Podobnikar, 2003). In 2005 a DEM 12.5 from different data sources was produced, which has roots in DEM 20 for $1 / 8$ of Slovenia that was produced in 2001 (Podobnikar, 2005a).

The old elevation models are unfortunately too coarse or of too low numerical and geomorphic quality for observing the human influences to the surface. In spite of the fact that older data are of lower quality, temporally 
different DEMs will help in the future to observe surface changes. At the moment, older maps of different scales and aerial photographs can help to digitise and describe some past surface changes, and therefore at least virtually preserve natural heritage to our descendant. In the future, environmental changes should be precisely observed and mapped in 3D. The series of surface changes in Slovenia should be therefore used for producing the DEMs that describe its changes over the time. The first DEMs that have been useful for observing the human impact (without the support of aerial photographs or satellite images) was DEM 25 with its first parts produced in 1995. The first DEM that was geomorphically continuously treated for all of Slovenia was DEM 12.5. On it we can clearly notice plenty of natural and anthropogenic changes. This data layer is a base for our mostly visual research of the human impacts to the terrain surface.

\section{VISUAL ANALYSIS}

Spatial analyses are among the most important capabilities of the geographical information systems. We distinguish between qualitative and quantitative analyses. Possible solutions of qualitative analyses can be explained with visualisations. This study is stressed on descriptive analyses that can answer to the basic questions on the spatial patterns. Unfortunately the quantitative spatial analyses tend to subjectivity in evaluation. With visual analyses of the significant parts Earth's surface, and with space-time series visualisation, we interpreted and understood some impacts for changes of the surface.

The course of Ljubljanica River had been much influenced by human demands at least since Roman period (Podobnikar and Šinkovec, 2004). On the Fig. 3 are visualised some previous river courses regarding some present-day data sources. The example $a$ describes a plan of Florjančič from 1744 where Gruber canal hadn't existed yet. On the picture $b$ Austrian $1^{\text {st }}$ Military Survey map that was produced between 1763 and 1787 is presented. The Gruber canal had already been mapped, but the lower course of Ljubljanica river was still much different from the present, which is presented as blue vector line over the map. Despite this data are only two-dimensional, we can easily imagine that river courses influence to the surface shape (e.g. Bec and Podobnikar, 2006). Surface changes can be examined by DEM 12.5 more detailed (c). We visualized them applying bipolar differentiation method with $3 \mathrm{~m}$ interval (Wood, 1996) in combination of hill shading (Podobnikar, 2005). Present Ljubljanica river and Gruber canal courses can be clearly observed in addition to railways, roads and quarries, etc. We can easily find correlations between the courses on the old maps ( $a$ and $b$ ) and patterns on the DEM (c). Regarding the other patterns on the DEM we can suspect positions of even much older (palaeo) river courses.

Higher precision LIDAR-DEMs will be in the near future applicable for many different fine patterns recognition. LIDAR-DEM with resolution of $1 \mathrm{~m}$ has so many details, that some patterns which seemed to be gross er- rors later were proved as consequences of the World War 1 (Fig. 4). Such data of the surface could help in the near future to reconstruct some missing facts of our history.

In general, to observe recent crucial surface changes are not needed that high precision data as it is a LIDARDEM. Some changes of the surface were observed on different versions of up to ten years old DEM 25 and on the newer DEM 12.5. These examples are continuous operations of the around gravel quarry Stanežiče near to Ljubljana and at stone quarry Stahovica near to Kamnik.

The DEM 12.5 on the Fig. 5 is visualised by hill shading, enhanced ridges and by hypsometry using different colours. Both, hill shading and enhancing the edges were modelled in different scales and with different parameters to emphasize multi-scale effect (Podobnikar, 2005a). On this cut out of the map, especially ridges are more visible perceivable with increasing brightness regarding natural aspect of the landform curvatures. For example, the result is similar with worn jeans on its edges or edges of table that became brighter. On the map can be noticed that most of the area is karstic with many dolinas or sinkholes. Besides of dolinas, a considering amount of human impact can be interpreted, too - especially very recent highways and a stone quarry. Less visible are older roads and railways.

On the Fig. 6 DEM 12.5 (a) and LIDAR-DEM 1 (b) are interpreted with direct comparison of both data of different resolution. On the picture a we can observe rough traces of coarser features like rings (walls) and lines (roads, railways), but all of the patterns are rather "blur". On the picture $b$ many more features and patterns can be observed. We can also do a visual quality control of the DEM 12.5 regarding more precise LIDAR-DEM 1 . We can see for example that some sinkholes on the lower left corner in the picture a are missing regarding the picture $b$. The errors are a result of more subjective manual measurements and mapping (generalisation) in the past, as this DEM was produced with fusion of about 30 data sources where the oldest are more than 50 years old. Higher quality LIDAR- 


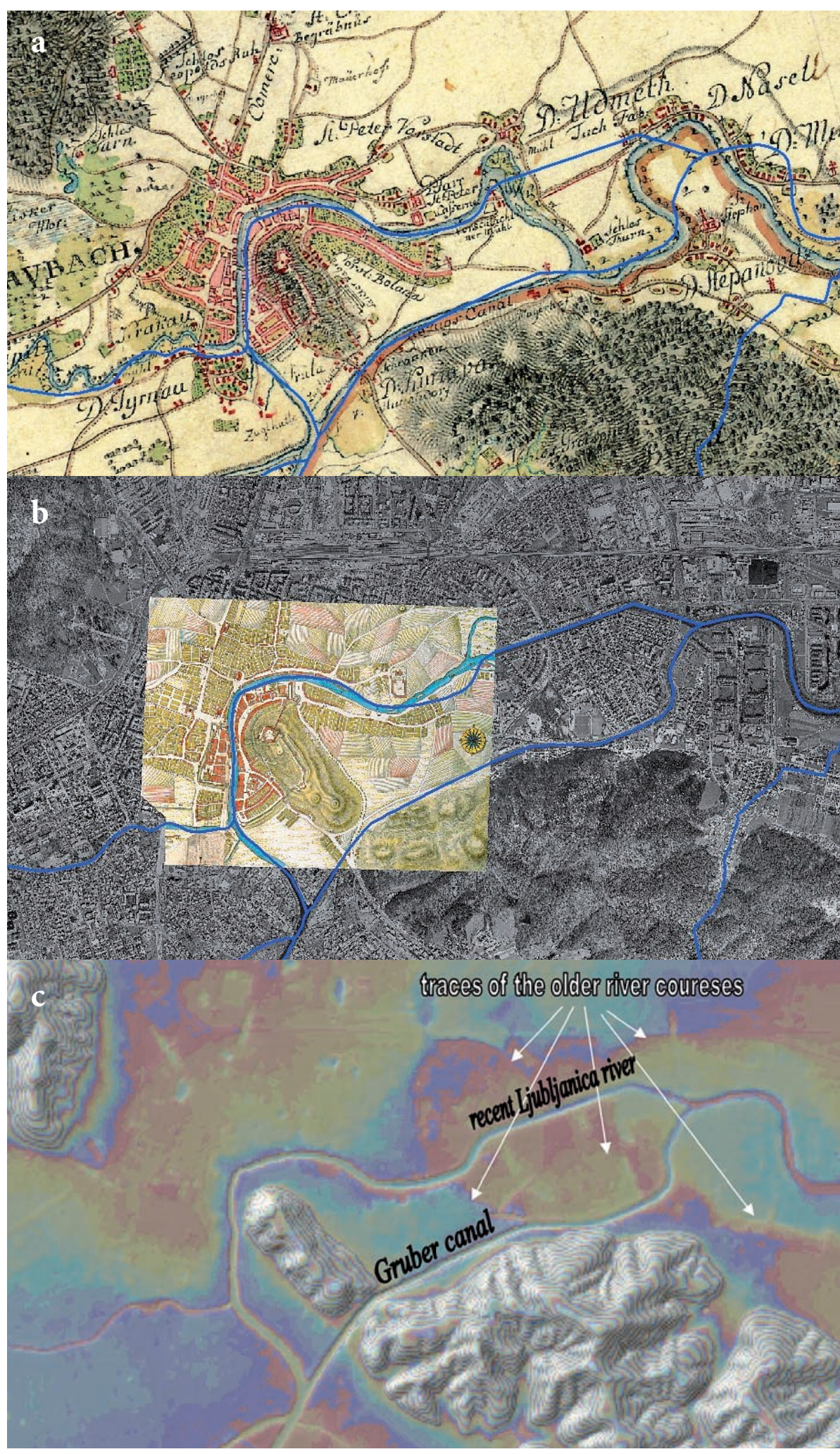

Fig. 3: Changes of the river courses: a: Florjančič plan without Gruber canal (DOP5, 2002 (C) Surveying and Mapping Authority of RS), b: Austrian 1st Military Survey map with the canal. Overlaid blue vector lines indicate current streams of the rivers. On the c: older river courses are recognisable (DEM 12.5, 2005 (C) Surveying and Mapping Authority of RS).
DEM 1 can be resampled to coarser resolution of $12.5 \mathrm{~m}$ and used for improvement of some remarkable wrongly interpreted areas on the DEM 12.5 during its processing (Podobnikar, 2005b).

On the Fig. 7 can be seen that rubbish dumps are easily perceivable on a DEM 12.5. They were compared with satellite images acquired from Google Earth (a). With terrestrial laser scanners we can measure smaller structures in a high precision and resolution with much lower expense than using airborne laser scanned data. The main advantages of LIDAR regarding classical surveying measurements are higher speed of surveying and almost continuous high precision data. The picture $b$ shows the velocity of filling some parts (fields) of Ljubljana's dump. Filling of this dump with rubbish is so fast, that monitoring can not gain upon up-to-dated DEM with appropriate accuracy, even for DEM of Slovenia with resolution of $12.5 \mathrm{~m}$ (DEM 12.5). On the picture a are described positions of the five fields and three phases and the status of the filling up process on the DEM (left) and Google Earth (right). Comparing a with $b$ we can see that data on the DEM 12.5 are probably from the first part of 2005, but on the Google Earth from the beginning of 2004 or before.

In parallel with DEM 12.5 modelling, layers of different structure lines of the Earth's surface were produced: ridges, valleys, sinkholes and peaks, layer of stone and gravel quarries, layer of all standing waters 


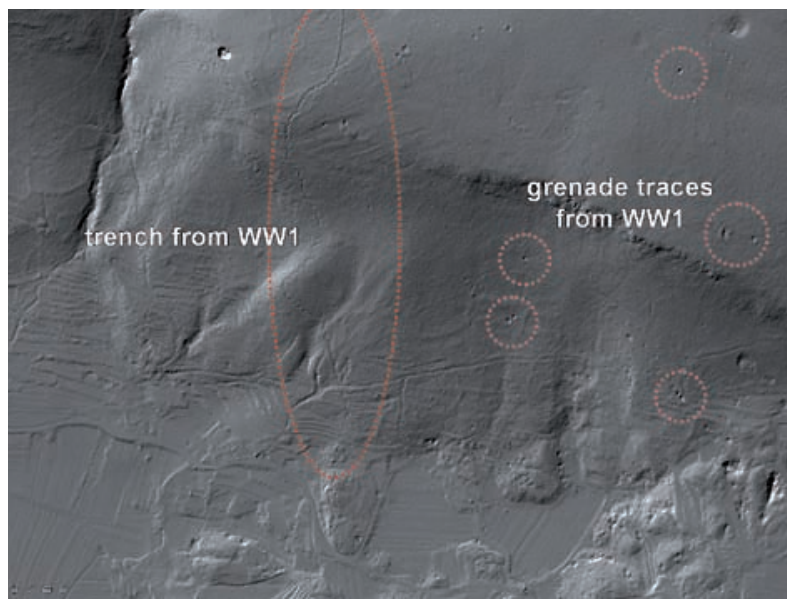

Fig. 4: Trench and grenade traces (LIDAR-DEM, Kobler, 2006).

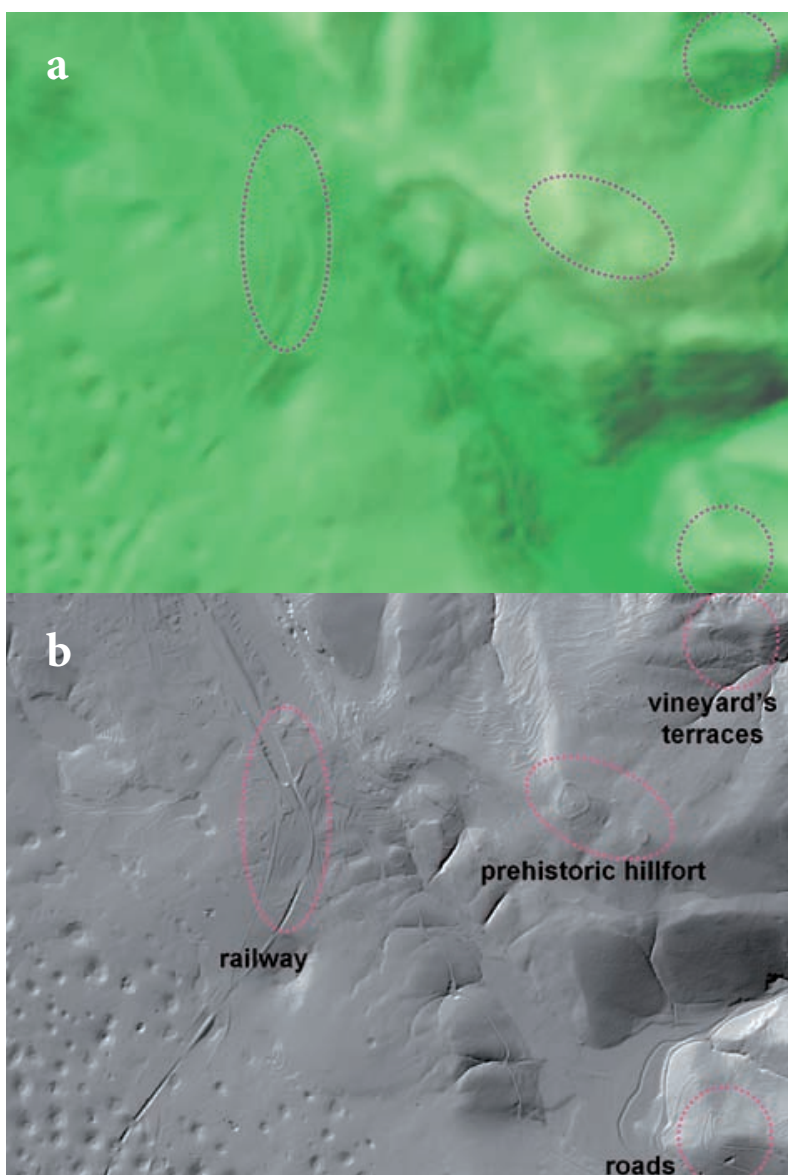

Fig. 6: Comparison of DEM 12.5 (a) and LIDAR-DEM 1 (b) on the same selected area. On the picture a we can observe many details, but there are still many uncertainties comparing $b$.

including artificial ones, and layer of different types of roads and railways. These particular data based mostly on the human impacts to the surface and can be used for monitoring of major Earth's surface changes. Qual-

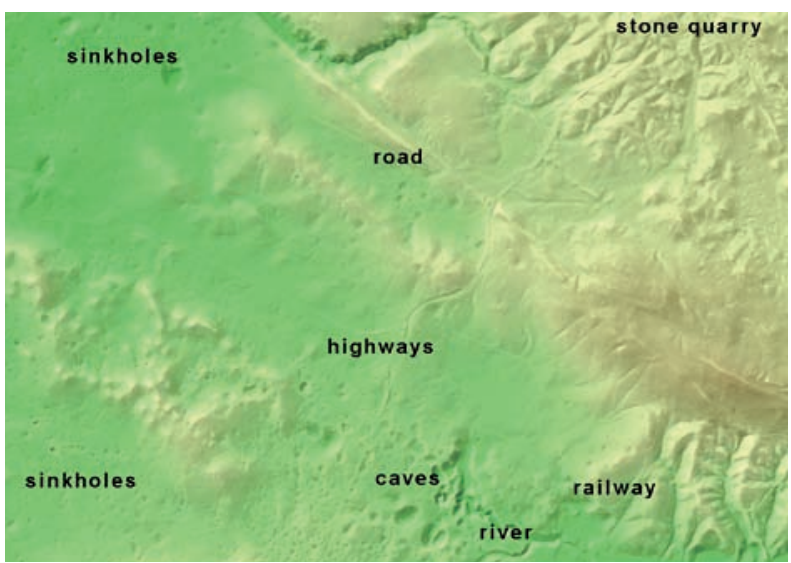

Fig. 5: Ancient and recent surface patterns (DEM 12.5, 2005 (c) Surveying and Mapping Authority of RS; map by Podobnikar, 2005a).

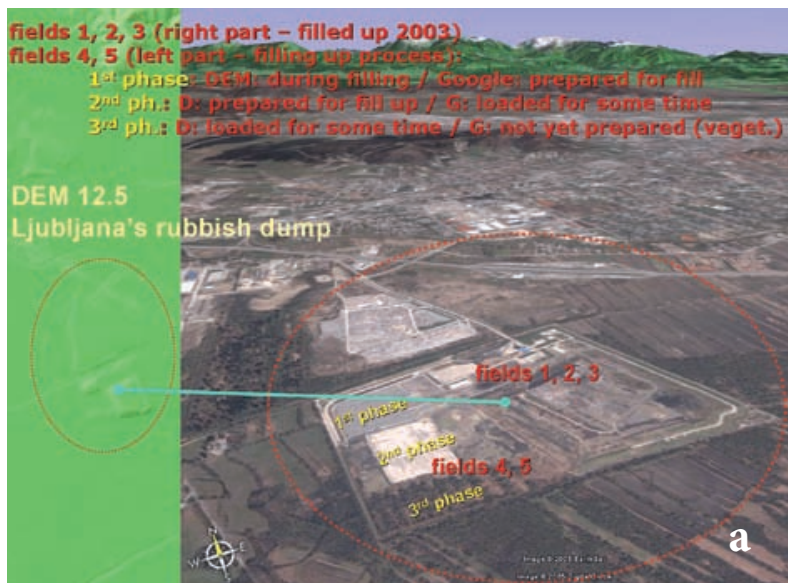

Ljubljana's rubbish dump; fields 4, 5 (LIDAR)

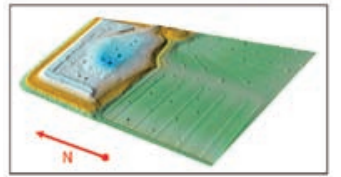

2004: 6 December

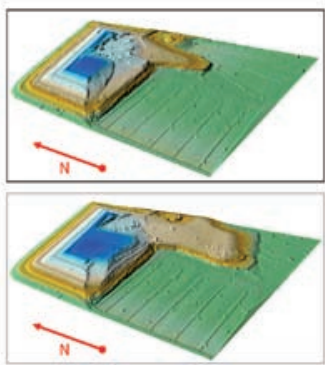
2005: 14 July
fWling up $2^{\text {m phase }}$ phas

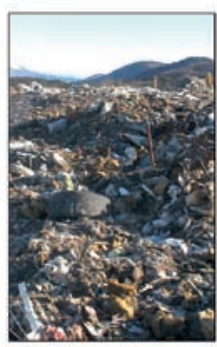

2006: 10 January

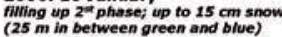

\section{b}

Fig. 7: a: Ljubljana's rubbish dump on a DEM 12.5 in comparison with the high resolution satellite image (Google Earth). $b$ : Phases of successive formation of the artificial hill that is rising, using terrestrial laser scanner (DFG SNAGA, 2006).

ity, especially height accuracy of all these data was also evaluated for every grid cell of $12.5 \mathrm{~m}$ (Podobnikar, 2005b). 


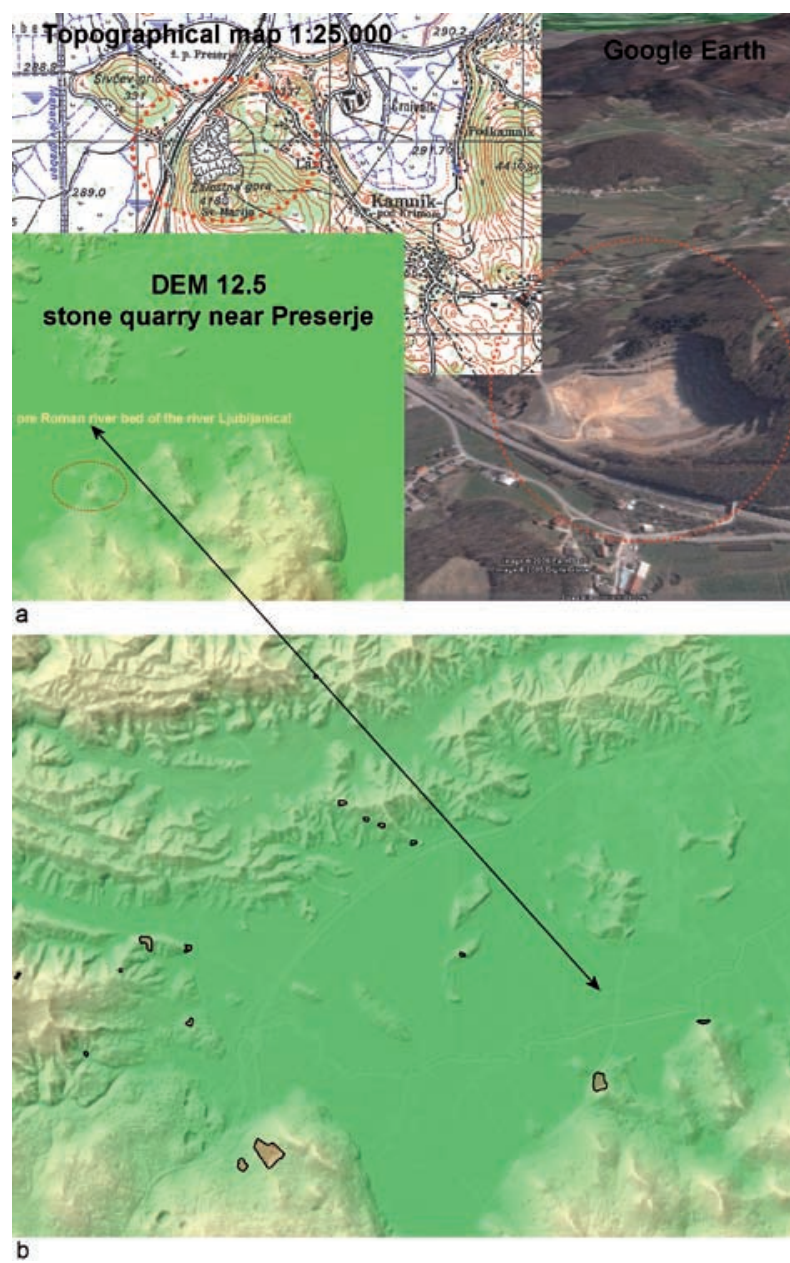

Fig. 8: In the picture a, stone quarry presented with DEM 12.5, symbol on topographical map in scale 1:25,000 (DTK25, (C) Surveying and Mapping Authority of RS), and as pattern on a satellite image (Google Earth). On the DEM, a pre Roman course of Ljubljanica river is noticeable. The stone and gravel quarries database around Vrhnika are presented in the $b$.

Stone and gravel quarries are clearly perceivable on the Fig. 8a: A DEM 12.5 is used for that presentation with its differences of heights, insertion of topographical map with their symbols and satellite image of Google Earth with recognisable patterns of the landscape were used. A detailed part of database is shown in the picture $b$ (cf. Fig. 1). This database might be compared with the official database. Comparison with the Corine Land Cover shows, that the latter doesn't contain most of the smaller quarries and their shape is rough.

Fig. 9 compares two groups of data sets. In the picture a all buildings, main roads and quarries are located. We can see that within some regions, most of area is settled or impacted by humans. On the picture $b$, the database of sinkholes distribution (produced for the

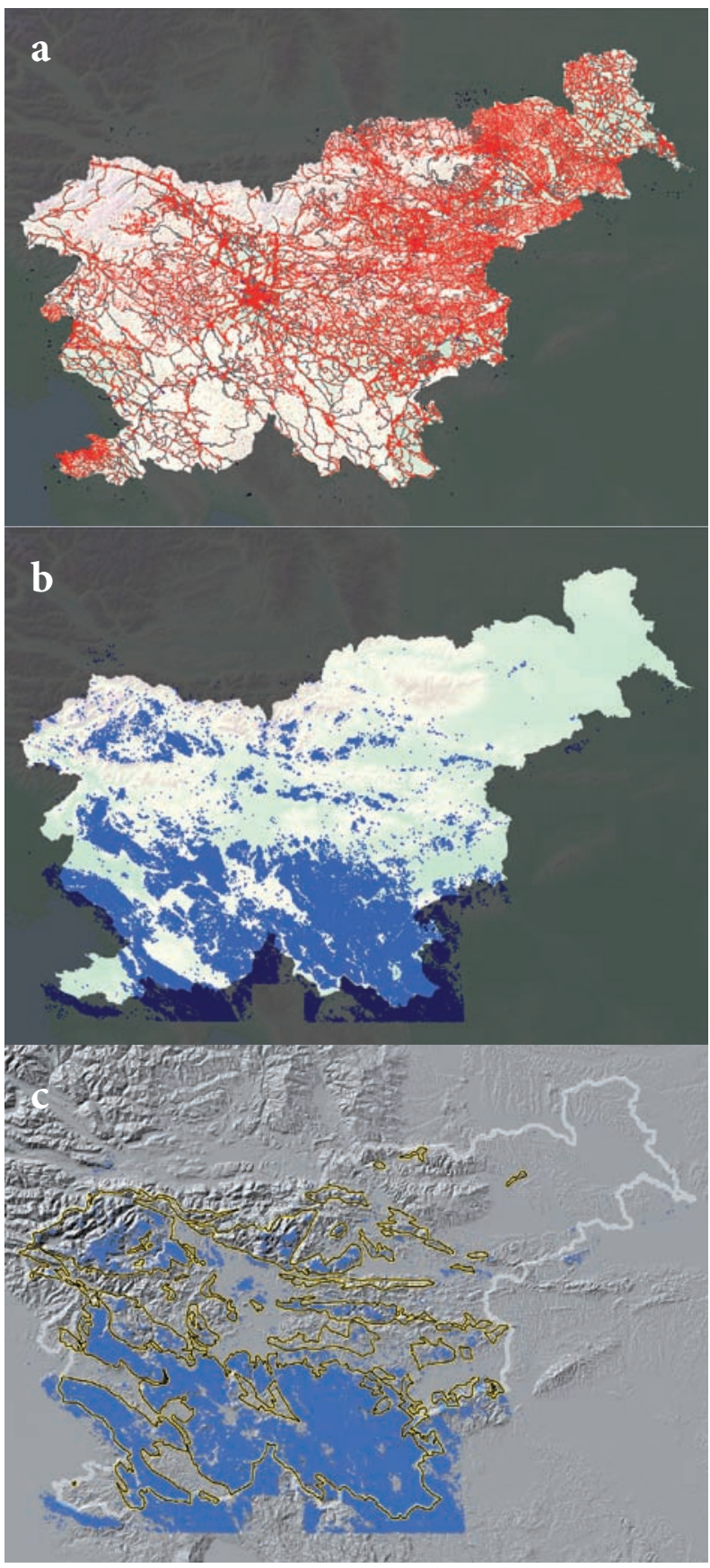

Fig. 9: a: Buildings, main roads (both (c) Surveying and Mapping Authority of RS), quarries as most of recent surface changes comparing with $b$ : distribution of sinkholes and $c$ : sinkholes comparing with karst areas in Slovenia (Čar, 1978).

DEM 12.5 modelling) shows that large part of Slovenia is potentially karst. The most interesting is comparing two visualisations. We can perceive complementarity of both pictures: areas that are built-up (a) are not much karstic (b). And opposite, karstic areas are not much built-up. 


\section{DISCUSSION AND CONCLUSIONS}

Current human's changes of the Earth's surface are just some of the many other aspects that changes beings on the Earth. We stressed this study on visualisations of the recent human impacts. We found out that they are much more visible than the changes, older than few decades ago. Most of the large surface changes are (fortunately?) invisible from the cities, roads, or paths. Numerical simulations refine and different visualisation strategies help to weigh up his decisions.

We found out that most of the human impacts are more visible on the Earth's surface than we could imagine before. Obviously the Slovenian environmental legislation can not manage some real interventions - at least considering stone quarries as important human's impacts (713 in our database). We noticed that the official database of non metal mineral row materials consists 685 locations. In ARSO (2002) is also noticed that those locations don't cause major environmental loading. Obviously they were not considered some significant environmental indicators in this research. With our analyses we found out even prehistoric walls, some later river regulations, ancient and recent land terraces for vineyards, bomb traces from the World War 1 are easily recognisable on the analysed data. Recognizing those old patterns is also of advantage, because that information could be useful for better understanding of our history, and the power of the current surface changes. With comparing of the outputs we have observed (but we haven't evaluated numerically) that are just one year old changes of surface greater than all of the changes until 19th century. The most recognisable current changes of the Slovenian surface are enlargements of quarries, new rubbish dumps, large buildings, and highways construction - especially on the specific karst areas. Karst area is vulnerable with its unique and uncovered surface, and subsurface (caves), karst water systems, water supply (poor filtration of water that penetrating), possible deforestation, etc.

Some of the human's impacts on the Earth's surface changes were visualised and numerically interpreted using georeferenced spatial data in Slovenia. We have demonstrated those changes by means of using high quality data, efficient tools and creative visualisation approaches. The study referred to DEM 12.5 and on its derivatives as quarries and sinkholes data sets. The secondary data sources were other DEMs, historical maps, and aerial photographs and satellite images. The DEM 12.5 was visualised by simple hill shading, hypsometry or more complex bipolar differentiation, enhancing of the edges, with multiscale presentations, etc. Visual mutual presentations of more data layers were more effective with comparing the same cut outs as "picture by picture" or transparently overlaid picture over the other picture. Preparing high quality data was necessary for the satisfactory results.

We found out that information about the past is important for understanding the development of the surface changes. For that the historical maps are important data. The recent satellite images and especially DEMs are important sources for tracking the human's changes through the time. For the experienced operator the visual methods - as they offer more semantic information - are at least at the first stages of research more practical than automated numerical methods. The visual methods could be source for the further automated methods for recognising possible artificial geomorphological artefacts. The presented visual methods already demonstrate some tools for detection of geomorphological features.

As was established also in Podobnikar and Kokalj (2007), the historical data are helpful for better understanding development of the human's impacts to environment. Unfortunately they are not much useful for systematic survey of the changes. The problem lies in thematic, positional and temporal homogeneity/accuracy of the data and also on the selection of the mapped themes. Particular changes that reflect significant changes of the environment (e.g. Gruber canal) were tracked through all data sources. On a high quality DEMs (DEM of Slovenia, LIDAR-based DEM) the traces of the many anthropogenic and natural changes (e.g. around Gruber canal) can be observed using only one data layer. Additionally the analyses should consider that overall quality of data sources generally increases by time.

Our society should more careful treat further interventions that can visually preserve the environment. Many possible solutions can lead to more sustainable development. Here are some possible examples. Transportation is a big problem, where especially the highways construction destroys a natural surface. Currently, only around 5\% of transport in Slovenia is carried by trains. For example, to the intelligent system could be connected more vehicles as automatically controlled convoys on the existent roads (automatic driving on short distances in between vehicles; IMTS, 2006) and on that way the impact could be lower. To the less impacts to the environment is connected a Happy Planet Index (HPI). It is intended to challenge well-known existing indices of a state's success, such as Gross Domestic Product and Human Development Index (NEF, 2006). It bases on the amount of the Earth's resources they use, and the length and happiness of people's lives. The HPI shows that people can live long, happy lives without using more than their fair share of the Earth's resources. On that way was 
for our use demonstrated that rapidly and much unpredictable changes of the Earth's surface are not source of the future happy environment. Some conservatism in the progress with much wisdom can lead to better live. Are we going to preserve unique and beautiful landmarks of Slovenia like they are presented by Burger (2006)?

\section{ACKNOWLEDGMENT}

All of the presented digital spatial data were not produced by the author. Some elevation models, aerial and terrestrial LIDAR measurements, orthophotos, historical and contemporary maps were kindly provided by following persons and organisations: Andrej Kobler - Sloveni- an Forestry Institute, Domen Smole - DFG Consulting, Irena Šinkovec - Municipal Museum of Ljubljana, and Surveying and Mapping Authority of RS, Franjo Drole - Karst research instate, ZRC SAZU

\section{REFERENCES}

ARSO, 2002: Okolje v Sloveniji 1996; Poročilo o stanju okolja 2002.- ARSO, http://www.arso.gov.si/ varstvo\%20okolja/poro\%C4\%8Dila/poro\%C4\%8Di la\%20o\%20stanju\%20okolja\%20v\%20Sloveniji/

Bec, D. and T. Podobnikar, 2006: Spreminjanje struge reke Save na Ljubljanskem polju / Changing of Sava's river channel on Ljubljana's field.- Geografski informacijski sistemi v Sloveniji 2005-2006, 133122, Ljubljana.

Čar, J., 1978: "Karst areas in Slovenia" produced on the basis of PKRS200.

Burger, B., 2006: Utrinki iz Slovenije/Slovenia Landmarks, http://www.burger.si/

Burrough, P.A. and R.A. McDonnell, 1998: Principles of Geographical Systems Information Systems. Spatial Information Systems and Geostatistics.- Oxford University Press, p. 333, Oxford.

Carlson, A., 2002: Environmental aesthetics., Routledge Encyclopedia of Philosophy.- Routledge, London, http://www.rep.routledge.com/article/M047SECT2

DARS, 2006: Družba za avtoceste v Republiki Sloveniji, d.d./Motorway Company in the Republic of Slovenia, http://www.dars.si

DFG SNAGA, 2006: Izmere telesa odlagališča nenevarnih odpadkov, odlagališče Ljubljana/Measuring of the dangerous garbage dump body, Ljubljana's dump; SNAGA, Javno podjetje, d.o.o., Ljubljana, realised by DFG CONSULTING, d.o.o., Ljubljana.

EKM, 2006: European Karst Museum. http://www.emk. si/

ESA, 2006: Observing the Earth.- European Space Agency, http://www.esa.int/esaEO/SEMA20W4QWD_ index_0.html
Google, 2006: Google Earth, Keyhole, Inc., http://earth. google.com/

IMTS, 2006: Intelligent Multimode Transit System, http://www.toyota.co.jp/en/tech/its/program/system/imts.html

Kobler, A., 2006: Shaded lidar-DTM, 1 m resolution.Slovenian Forestry Institute. Ljubljana.

Komac, M., 2006: Za koliko se dvigujejo Alpe? : Natančno opazovanje relativnih vertikalnih premikov površja s pomočjo satelitov.- Delo, 2006-0824, 20, Ljubljana.

NEF, 2006: New Economics Foundation. http://www. neweconomics.org/gen/, http://www.happyplanetindex.org/

Oštir, K., 2000: Analysis of the influence of radar interferogram combination on digital elevation and movement models accuracy.- PhD thesis, Department of Geodesy, University of Ljubljana, p. 175, Ljubljana.

Podobnikar, T. \& I. Šinkovec, 2004: Ljubljana - mutual analyses of the georeferenced old maps.- Javno dobro : indentifikacija, upotreba, upravljanje, dizajn : zbornik radova, Centar za planiranje urbanog razvoja, 67-73, Beograd.

Podobnikar, T. \& K. Zakšek, 2005: GIS analysis "Menina planina”, Slovenia : documentation of GIS concepts, methods and results. Ljubljana, http://stratus.meteotest.ch/windharvest/report_gis_slo.pdf

Podobnikar, T. \& Ž. Kokalj, 2007: Triglav National Park Historical Maps Analysis.- 5th ICA Mountain Cartography Workshop, Bohinj, 29 March - 1 April 2006, 180-188, Ljubljana. 
Podobnikar, T., 2003: Kronologija izdelave digitalnega modela reliefa Slovenije/Chronology of digital terrain model production of Slovenia.- Geodetski vestnik, 47, 1/2, 47-54. Ljubljana.

Podobnikar, T., 2005a: Karta površja Slovenije / Surface Map of Slovenia.- Surveying and Mapping Authority of the Republic of Slovenia \& Scientific Research Centre of Slovenian Academy for Sciences and Arts, Ljubljana.

Podobnikar, T., 2005b: Production of integrated digital terrain model from multiple datasets of different quality.- International journal of geographical information science, 19, 1, 69-89, Leicester.
Podobnikar, T., 2007: DEM from Various Data Sources and Geomorphic Details Enhancement.- 5th ICA Mountain Cartography Workshop, Bohinj, 29 March - 1 April 2006, 189-199, Ljubljana.

VRM, 2003: Visual Resource Management. U. S. Department of the Interior - Bureau of Land Management http://www.blm.gov/nstc/VRM

Wood, J., 1996: The Geomorphological Characterisation of Digital Elevation Models.- PhD thesis, Department of Geography, University of Leicester, p. 185, Leicester. 
